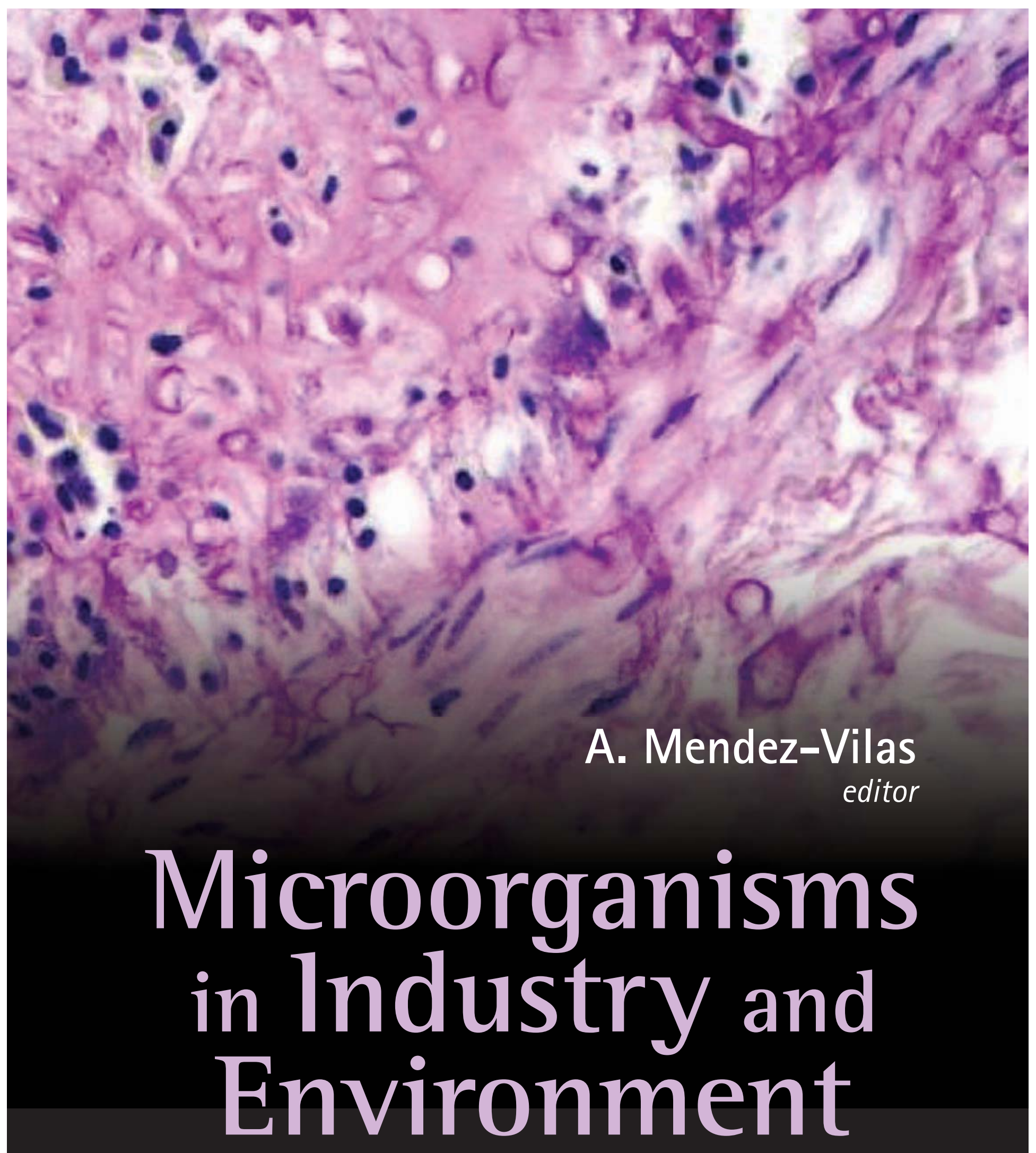

From Scientific and Industrial Research to Consumer Products 


\section{Microorganisms in lndustry and Environment}

From Scientific and Industrial Research to Consumer Products 
This page is intentionally left blank 


\section{Microorganisms in Industry and Environment}

From Scientific and Industrial Research to Consumer Products

Proceedings of the III International Conference on Environmental, Industrial and Applied Microbiology (BioMicroWorld2009)

Lisbon, Portugal $\quad 2-4$ December 2009

\section{editor \\ A. Mendez-Vilas}

Formatex Research Center, Spain \& University of Extremadura, Spain 
Published by

World Scientific Publishing Co. Pte. Ltd.

5 Toh Tuck Link, Singapore 596224

USA office: 27 Warren Street, Suite 401-402, Hackensack, NJ 07601

UK office: 57 Shelton Street, Covent Garden, London WC2H 9HE

British Library Cataloguing-in-Publication Data

A catalogue record for this book is available from the British Library.

MICROORGANISMS IN INDUSTRY AND ENVIRONMENT

From Scientific and Industrial Research to Consumer Products

Proceedings of the III International Conference on Environmental, Industrial and Applied Microbiology (BioMicroWorld2009)

Copyright () 2011 by World Scientific Publishing Co. Pte. Ltd.

All rights reserved. This book, or parts thereof, may not be reproduced in any form or by any means, electronic or mechanical, including photocopying, recording or any information storage and retrieval system now known or to be invented, without written permission from the Publisher.

For photocopying of material in this volume, please pay a copying fee through the Copyright Clearance Center, Inc., 222 Rosewood Drive, Danvers, MA 01923, USA. In this case permission to photocopy is not required from the publisher.

ISBN-13 978-981-4322-10-2

Printed in Singapore by Mainland Press Pte Ltd. 


\section{Introduction}

This book contains a selection of works that were presented during the third International Conference on Environmental, Industrial and Applied Microbiology (BioMicroWorld2009), which took place at the University of Lisbon, in Lisbon (Portugal), from 2-4 December 2009. The conference was attended by more than 600 participants from 54 countries, thus consolidating the BioMicroWorld conference series, initiated in Badajoz (Spain) in 2005. The conference presentations and discussions were structured around different general and specific themes:

- Environmental Microbiology. Geomicrobiology • Agriculture, Soil, Forest Microbiology • Food Microbiology - Industrial Microbiology — Future Bioindustries • Methods - Analytical \& Imaging Techniques • Medical \& Pharmaceutical Microbiology. Antimicrobial Agents • Microbial Physiology, Metabolism and Gene Expression - Biofilms \& Antimicrobial Surfaces • Bioremediation • Biotechnologically Relevant Enzymes and Proteins • Microfactories — Microbial Production of Chemicals and Pharmaceuticals.

The Conference could not be as successful as it was without the work of a group of professionals and researchers forming the conference Scientific Advisory Committee in charge of selecting the most relevant works submitted to be considered for presentation during the conference. In this edition, the members were:

Jose Luis Martinez, National Center for Biotechnology, Spain; Kaarina Sivonen, University of Helsinki, Finland; Nuno F. Azevedo, University of Porto, Portugal; Yan Zhang, Peking University, China; Pei-Yuan QIAN, The Hong Kong University of Science and Technology, Hong Kong; Sergey V. Kalyuzhnyi, Moscow State University, Russia; Hong Kai WU, The Hong Kong University of Science and Technology, Hong Kong; Yves Blache, Université du Sud Toulon-Var, France; Megharaj Mallavarapu, University of South Australia, Australia; Kostas Koutsoumanis, Aristotle University of Thessaloniki, Greece; Gerardo R. Vasta, University of Maryland, USA; Elke Nevoigt, Catholic University of Leuven, Belgium; Peter Gerner-Smidt, Centers for Disease Control and Prevention, USA; Rosario Muñoz, Institute of Industrial Fermentation, Spain; Jan Michiels, Catholic University of Leuven, Belgium; Alban Ramette, Max Planck Institute for Marine Microbiology, Germany; Sigrid De Keersmaecker, Catholic University of Leuven, Belgium; Nigel Robinson, Newcastle University, United Kingdom; Ramesh C Kuhad, Universiy of Delhi South Campus, India; Raeid M. M. Abed, Sultan Qaboos University, Sultanate of Oman; Petr Baldrian, Institute of Microbiology ASCR, Czech Republic; Joseph Kreit, Mohammed V University, Morocco; Pilar García, Asturias Dairy Products Institute, Spain; Wim Crielaard, Academic Center for Dentistry Amsterdam, Netherlands; R. Kumar Malik, National Dairy Research Institute, India; Juan José Valdez Alarcón, Michoacana University of Saint Nicolas Hidalgo, Mexico; Rakesh K. Jain, Institute of Microbial Technology, India; Badal C. Saha, National Center for Agricultural Utilization Research, USA; Bo Mattiasson, Lund University, Sweden; Essaid Ait Barka, University of Reims, France; Ibrahim Banat, University of Ulster, United Kingdom; Ece Karatan, Appalachian State University, USA; Hermann J. Heipieper, Helmholtz Centre for Environmental Research UFZ, Germany; Carme Plumed-Ferrer, University of Kuopio, Finland; Filip Boyen, Gent University, Belgium; Chao-Ying Chen, National Taiwan University, Taiwan; Rodney M. Donlan, Centers for Disease Control and Prevention, USA; Bruce A. Maguire, Pfizer Global Research and Development, USA; Douglas B. Weibel, University of Wisconsin-Madison, USA; Veronica Arthurson, Swedish University of Agricultural Sciences, SLU, Sweden; Götz Haferburg, Institute of Microbiology at the Friedrich Schiller University of Jena, Germany; Agneta Richter-Dahlfors, Swedish Medical Nanoscience Center, Sweden; Anil Kumar Puniya, National Dairy Research Institute, India; Renu Agrawal, Central Food Technological Research Institute, India.

There were three Plenary Lectures during the conference, one per day, which attracted a large percentage of the registered participants. They were excellent examples of currently relevant interdisciplinary research in applied microbiology:

Hermann Heipieper from the Helmholtz Centre for Environmental Research - UFZ, Germany, talked about "Microbial Adaptation to Toxic Organic Solvents - Mechanisms and Biotechnological Applications".

Stefan Dübel from the Institute for Biochemistry and Biotechnology, Technical University of Braunschweig, Germany, talked about "Antibodies from Bacteria".

Rosário de Oliveira from the Department of Biological Engineering, University of Minho, Portugal, talked about "Insights into the Biofilm World". 
Last but not least, we acknowledge the support of the sponsors of this edition, namely, Bertin Technologies (http://www.bertin.fr) and the organizer of the 13th International Symposium on Microbial Ecology (ISME13, http://www.isme-microbes.org/isme13). The support of publishers Springer, Elsevier, and Science Publications, through their journals Biodegradation, Journal of Industrial Microbiology \& Biotechnology, Journal of Biotechnology, and American Journal of Agricultural and Biological Science, is also acknowledged.

We hope the current book accurately reflects some of the major current topics covered in the conference and we look forward to receive your presentations at the next BioMicroWorld edition.

Antonio Méndez-Vilas

BioMicroWorld2009 General Coordinator, on behalf of the Organizing Committee

Formatex Research Center

C/Zurbaran, 1, 2nd Floor, Office 1

06001 Badajoz

Spain 


\section{Contents}

Introduction

\section{Agriculture and Soil Microbiology}

Ability of Ralstonia solanacearum phylotype II to adapt to environmental prevailing factors in water Belén Álvarez, María M. López and Elena G. Biosca.

Analysis of microbial communities under long-term conventional and reduced-input management of tillage soil

Sagar Chhabra, Jill Hogan, David Ryan, Jim Burke, Dina Brazil and David N. Dowling.

Antimicrobial activity of chitosan against Fusarium oxysporum f. sp. tracheiphilum

T.C.M. Stamford, S.R.C. Alcântara, L.R.R. Berger, N.P. Stamford, M.C.F. Silva, T.K.S. Borges,

D. Laranjeiras and G.M. Campos-Takaki.

Aspects about virulence and epiphytic fitness of Pseudomonas syringae pv. syringae strains isolated from mango trees

E. Arrebola, V. Carrión, J.C. Codina, A. Pérez-García, F.M. Cazorla and A. de Vicente....

Characterization of rhizospheric bacteria isolated from maca (Lepidium meyenii W.) in the highlands of Junin-Peru

D. Zúñiga Dávila, J. Tolentino Macalupú, M. García Wong, W. Pérez Porras,

M. Matsubara Bautista and K. Ogata Gutiérrez

Detection of group I and group II introns in a Mexican Bacillus thuringiensis collection A. Espino-Vázquez, A. Solís-Soto, H.A. Luna-Olvera, H. Medrano-Roldán and B. Pereyra-Alférez ......

Determination of soil microbial community fluctuations by different techniques in a maize field Ana Muñoz, Antonio López-Piñeiro, José A. Regodón and Manuel Ramírez....

Differences between microbial communities in worm guts and the soils they inhabit R.M. Simpson, M. Picquet and M. Deurer

Effect of different rhizospheric bacteria in the growth of Gossypium barbadense L. in Perú

D. Yino Oshiro, L. Ramos Pajuelo, M. Matsubara Bautista, L. Espinoza Melgar and

D. Zuñiga Dávila.

Effect of in vivo passage on spore germination and virulence of Verticillium lecanii Ali Derakhshan

Erwinia amylovora colonization of host plants inoculated by irrigation R.D. Santander, E. Marco-Noales, M. Ordax and E.G. Biosca

Evaluation of flow cytometry to assess Erwinia amylovora viability under different stress conditions R.D. Santander, J.F. Catalá-Senent, M. Ordax, A. Flores, E. Marco-Noales and E.G. Biosca.

Genetic variability analysis of entomopathogenic fungi isolated from citrus-growing areas of Mexico A.L. Galán-Franco, K. Arévalo-Niño, M. Elías-Santos, A Morales-Loredo, G. Alvarez-Ojeda,

J.I. López-Arroyo and I. Quintero-Zapata....

Identification of virulence genes in Fusarium oxysporum $f$. sp. lycopersici the causal agent of tomato wilt disease

M.L.R. Bastos da Silva, M.C.C. Pereira de Lyra, I.R. Souza Arruda, M. Vanusa da Silva and

J. Zoé Brito.

Influence of organic and conventional soil management system on soil respiration and enzymatic activity

L. Dubova, V. Šteinberga, O. Mutere, I. Jansone and I. Alsinga .... 
Microbial analysis of soils from avocado crop modified by organic amendments

N. Bonilla, F. M. Cazorla, J.M. Hermoso, J. González J.A. Torés and A de Vicente

Modeling of nitrogen leaching by using urea fertilizer in sandy loam soil

Khalil Ajdary and Hamid Zare Abianeh.....

Mutual influence of the non-symbiotic soil basidiomycete, Stropharia rugoso-annulata and white mustard plants on their enzymatic activities under natural conditions

G. Gramss and H. Bergmann

Nematicidal activity of Solanum sisymbriifolium and S. nigrum extracts against the root-lesion nematode

Pratylenchus goodeyi

M. Pestana, M. Rodrigues, L. Teixeira, I.M. de O. Abrantes, M. Gouveia and N. Cordeiro.....

Particular characteristics of soil microbial communities in forest stands infected with Heterobasidion parviporum and Armillaria spp.

L. Grantina, E. Seile, U. Malinovskis, G. Tabors, R. Kasparinskis, V. Nikolajeva and I. Muiznieks ......

Pathogenic bacteria can produce exopolysaccharides and use them as carbon source under stress conditions: the case of Erwinia amylovora

M. Ordax, E. Marco-Noales, M.M. López and E.G. Biosca.

Phenotypic characterization and the application of the rep-PCR technique in a study of new strains of Bacillus thuringiensis in the South of Brazil

G. Cristina Alles, V. Machado and L. Mariana Fiuza.

Phytophthora parasitica showing host specificity and pathogenic ability on tomato and sweet pepper

M. de Cara, D. Palmero, C. Durán, C. Lacasa, M. Santos, M.D. Coffey and J.C. Tello..

Polybiotrophy of Serratia marcescens, a causative agent of an onion disease in arid zone of the South of Ukraine

L. Ovcharenko, T. Voznyuk, I. Zaetz, A. Potopalsky, O. Reva and N. Kozyrovska

Polyphenol oxidase in golden chanterelle (Cantharellus cibarius) mushroom

Jacqueline Keyhani and Ezzatollah Keyhani

Prevalence of plant pathogenic isolates of airborne Fusarium species in south east coast of Spain D. Palmero, J.M. Rodríguez, M. de Cara, F. Camacho, C. Iglesias and J.C. Tello

Production of beer using sorghum and sorghum malt

P.J. Segura, M. Lozano-Contreras, V. Mojica-Marín, M.G. Maldonado-Blanco, H.A. Luna-Olvera,

J.L. Meza-García, B. Pereyra-Alferéz, I. Quintero-Zapata and M. Elías-Santos.....

Sequencing of the region of ribosomal internal transcribed spacer (ITS) of Metarhizium anisopliae in Pernambuco state

M.L.R.B da Silva, V.A.L.B Cavalcanti, A.C.E.S Mergulhão and M.C.C.P de Lyra

Soil bioremediation of atrazine pesticide by two strains of soil microorganism

Ana Muñoz, Antonio López-Piñeiro, José. A. Regodón and Manuel Ramírez.....

Study on the effects of nitrogen, glucose and plant residues on soil microbial C

S. Shahsavani and G. Shakeri.....

The toxicity and histopathology of Bacillus thuringiensis Cry1Ba toxin to Spodoptera frugiperda (Lepidoptera, Noctuidae)

L. Massochin Nunes Pinto, N. Carolina Drebes Dörr and L. Mariana Fiuza.....

\section{Environmental Microbiology}

A bacterial consortium alleviated a low-dose gamma-irradiation effect in Kalanchoe plantlets O.P. Boorlak, I.S. Rogutskyy, B.A. Danilchenko, O.M. Mikheev, I.Ye. Zaets, A.I. Vasilenko, J.-P. de Vera, B.H. Foing and N.O. Kozyrovska..... 
Assessment of the collaboration between fungi and bacteria during the oxalate-carbonate pathway in microcosms

M. Guggiari, G. Martin, M. Aragno, E. Verrecchia and D. Job

Diversity of foaming producing nocardioform actinomycetes from wastewater treatment plants in Spain

G. Cuesta, A. Soler, J.L. Alonso, J.J. Morenilla and Bernacer I ....

Effect of a respiratory inhibitor on the bioconversion of a xenobiotic by activated sludge

A.M.T. Mata, N.D. Lourenço and H.M. Pinheiro

Environmental impact on Rhizobium sp. cells

Radha Bhattacharya

INDISIM-SOM: an individual-based simulator on a website for experimenting with and investigating diverse dynamics of carbon and nitrogen in mineral soils

A. Gras, J.C. Cañadas and M. Ginovart

Influence of the fungicide Benomyl and ecophysiological factors on growth rate of Fusarium

verticillioides and Fusarium proliferatum from Spain

P. Marín, N. Magan, A. Cruz and M.T. González-Jaén.

Influence of the heavy metals on chitosan production by Absidia corymbifera UCP 0134

A. Cardoso, A. Marques, P. Homero Campos Marinho, R. Kenji Shiosaki and

G. Maria Campos Takaki.

Involvement of oxidative stress in UV-induced impairment of bacterial activity and culturability Ana L. Santos, Inês Baptista, Vanessa Oliveira, Isabel Henriques, Newton C.M. Gomes,

Adelaide Almeida, António Correia and Ângela Cunha....

Isolation of the extreme halophiles from rock salt

K. Watanabe, J. Ueda, Y. Sasakawa, M. Watarai, K. Nakamura, K. Yamaguchi, M. Aoki,

T. Kanazawa, K. Yamazaki, H. Takee, R. Kushida and N. Kurosawa.

Quantification and toxicity testing of pharmaceuticals in tropical marine sediments, All Saints Bay,

Bahia, Brazil

M. Beretta, L. Wessels Perelo and I. Brandão de Oliveira.

Relationships between hydrophobicity and biofilm formation in Streptococcus agalactiae strains V. Giummarra, M.C. Scuderi, G. Tempera, L.S. Roccasalva and P.M. Furneri.

Role of catalases in isolates of genus Comamonas from a polluted environment M. Bučková, J. Godočíková, M. Zámocký and B. Polek.

Saccharomyces cerevisiae $\mathrm{UE}_{-\mathrm{ME}_{3}}$ is a good strain for isoproturon bioremediation?

M. Candeias, I. Alves-Pereira and R. Ferreira.

Thermophilic bacteria isolated from a personal-use composting reactor

K. Watanabe, Y. Nakane, K. Nakagawa, T. Sakaguchi and N. Kurosawa

Ultrastructural behavior of Rhodotorula mucilaginosa induced by the growth in presence of pyrene

P. Homero Marinho, P. Mendes Souza, M. Antônio Lima, R. Burgos, A. Cardoso,

A. Elesbão Nascimento and G. Campos Takaki....

Vanadium pentoxide: an oxidative stress agent which disturbs glutathione conjugates metabolization in Saccharomyces cerevisiae $\mathrm{UE}_{-\mathrm{ME}_{3}}$

S. Gonçalves, R. Ferreira and I. Alves-Pereira

Vertical profile of bacterial community in the sediment of Ulleung Basin: implication of the presence of methane-driven community

In Soon Jeong, Jang-Cheon Cho, Jang-Jun Bahk, Sang Min Hyun, Kae Kyoung Kwon,

Jung Hun Lee, Sung Gyun Kang, Sang Hee Lee and Jung-Hyun Lee. 
Volatile fatty acids separation by ion exchange chromatography in fixed bed column

A.C. Malvestio, M. Barboza, J.A.C. Leite and M. Zaiat.

\section{Bioremediation}

Bioremediation of heavy metals through symbiosis between leguminous plant and rhizobium with engineered metallothionein and phytochelatin synthase genes

Yoshikatsu Murooka, Akiko Ike and Mitsuo Yamashita

Influence of readily assimilated carbon sources on the phenol degradation of Trichosporon cutaneum R57 strain

M. Gerginova, N. Shivarova, N. Peneva, H. Yemendzhiev and Z. Alexieva

Reactive Violet 12 dye decolorization by mycelial culture of Trametes versicolor

A. Krastanov, H. Yemendzhiev, I. Stoilova and Z. Alexieva

Spent mushroom substrate from the industrial cultivation of $P$. ostreatus for discoloring complex chromo-baths for the textile industry: white rot fungi for a sustainable approach to wastewater treatment Simona Di Gregorio, Francesco Balestri, Maria Basile, Valentina Matteini, Francesco Gini, Stefania Giansanti, Maria Grazia Tozzi, Riccardo Basosi and Roberto Lorenzi.......

Sustainable remediation of polycylic aromatic hydrocarbon contaminated soils using a two-step bioremediation process

J. Hall, R. Stewart, B. Dearman and A.S. Ball

The decolorization of azo dyes by Trametes versicolor under the influence of different glucose concentrations

H. Yemendzhiev, Z. Alexieva, I. Stoilova and A. Krastanov

The sequential photo-biodegradation of MCPA with the use of excilamps

Karetnikova Elena A., Tchaikovskaya Olga N., Sokolova Irina V. and Kaharova Anna I.

Uranium adsorption by Articulospora tetracladia: can aquatic hyphomycetes be natural bioremediators of uranium contaminated streams?

V. Ferreira, A.L. Gonçalves, J. Pratas and C. Canhoto

\section{Biofilms}

Biofilm development during an anaerobic wastewater treatment process

I. Schneider and Y. Topalova

Biofilm formation by algae on sandstone monuments and their inhibition: a case study of Agra (India)

Alka Jain and Seema Bhadauria

Comparison of methods for the detection of biofilm production in coagulase-negative staphylococci

A. Oliveira, M. Fávero Bonesso and M.L.R. de Souza da Cunha

Differences between clinical and food isolates of Listeria monocytogenes in biofilm formation J. Barbosa, V. Ferreira, S. Borges, R. Camilo, J. Silva, R. Magalhães, I. Santos, G. Almeida,

P. Gibbs and P. Teixeira.

\section{Industrial Microbiology}

Biocidal potential of essential oils of Piper aduncum, Piper hispidinervum and Syzygium aromaticum on important pathogenic and toxigenic microorganisms important for food

C.R. Giviziez, L.R. Batista, M.G. Cardoso, W.C. Ferreira, C.R. Bottura and M.C. Andrade

Bioprospection of microorganisms for lipase production using an industrial waste as carbon source

D. Silva Gomes, E.L. Vera Cruz, L. Asfora Sarubbo, G.M. Campos Takaki and

A. Amorim Salgueiro 
Biosynthesis of the lipids by the yeasts Rhodotorula gracilis

Sergiy Shulga, Alla Tkachenko and Nataly Beyko.....

Degradation assay of lignocellulosic compounds in combination with polyurethane resin by CECT fungi

F. Llinares, R. Díaz, M. De Troya and P. Jiménez....

Design of surface response analysis of $K_{\mathrm{La}}$ depending on aeration and agitation rate in a $14 \mathrm{~L}$ bioreactor

F. Rodríguez-Gómez, M. Lozano-Contreras, M.G. Maldonado-Blanco, H.A. Luna-Olvera,

C.F. Sandoval Coronado, F. Vilcanquí-Pérez, L.J. Galan-Wong and M. Elías-Santos.

Effect of oxidized cellulose on probiotic bacteria

P. Snevajsova, J. Vytrasova and J. Remesova

Effect of $\mathrm{pH}$ and inoculum percentage on canthaxanthin production by Dietzia maris

G. Goswami, S. Chaudhuri and D. Dutta.

Isolation and characterization of cellulase producing bacteria from pruning tree compost and soil

Junko Ueda, Keiko Watanabe, Shuichi Yamamoto and Norio Kurosawa.

Mixture design of agricultural waste substrates for laccase production from white rot fungus

T. Chairin, C. Khanongnuch and S. Lumyong ......

Optimization of a protoplast transformation method for Bacillus subtilis, Bacillus megaterium, and

Bacillus cereus by a plasmid pHIS1525.Sp lipA $_{\text {A }}$

A. Mirabdollah, S. Alinezhad, E. Feuk-Lagerstedt and I. Sárvári Horváth.....

Optimization of the continuous clavulanic acid adsorption process

Renata M.R.G. Almeida, Marlei B. Pasotto and Carlos O. Hokka.....

Potential of microbial consortium for biological treatment of the effluent from cassava flour production E.L. Vera Cruz, R. Albuquerque Lima, L. Asfora Sarubbo, G.M. Campos Takaki and

A. Amorim Salgueiro

Salmonella enterica Typhimurium: establishment of cultivation condition on shake flask and flagellin isolation strategy by using tangencial ultrafiltration

B.H. Oliveira, M.R. Silva, C.J.M. Braga, L.M. Massis, L.C.S. Ferreira and

M.E. Sbrogio-Almeida M. Takagi. . 348

\section{Food Microbiology}

Antimicrobial activity of extracts from different Origanum vulgare clones grown in Latvia

I. Alsing, L. Dubova, Z. Krūma, J. Krainis, I. Žukauska and R. Galoburda ..

Behavior of Shiga-toxin-producing Escherichia coli (STEC) of serotype O113:H21 to front pH, water activity, time and temperature

L. Justo Beserra, A.M. Figueiredo Cerqueira, K.G. de Lima Araújo, J.R. Costa Andrade and

A.G. Martins Gonzalez.

Betalactam resistance in food Escherichia coli isolated from broilers

Kmet Vladimir, Dobroslava Bujnakova, Zuzana Drugdova and Marta Kmetova.

Biocontrol of Penicillium expansum with yeast

M. Domenech Lucas, C. Vázquez Estévez, M.T. González-Jaén and B. Patiño Álvarez

Detection and antibiotic susceptibility of coliform bacteria in fresh vegetables

M.P. Falomir, D. Gozalbo, C. Sebastiá and H. Rico

Effect of carbendazim and water activity on the growth of Aspergillus ochraceus and ochratoxin A accumulation in solid medium containing bee pollen

M.A. García-Esparza, Eva M. Mateo, F.M. Valle-Algarra, R. Mateo-Castro and

M. Jiménez 
Efficacy of three antifungal chemicals on the growth in vitro of Aspergillus ochraceus and Aspergillus carbonarius strains isolated from Spanish barley

Eva M. Mateo, A. Medina, F.M. Valle-Algarra, F. Mateo, M.A. García Esparza and M. Jiménez.

Evaluation of the persistence of viable L. monocytogenes cells in chlorinated water Y. Moreno, M.C. Sanchís, L. Ballesteros, A. González and M.A. Ferrús.

Fusarium spp. occurrence in feeds and cereal grains (Portugal-2007) Inês Almeida, H. Marina Martins, Marta Marques and F. Bernardo.

Identification and characterization of yeasts isolated from oleic ecosystems

Sheila Romo-Sánchez, Milla Alves-Baffi, María Arévalo-Villena, Juan Úbeda-Iranzo and

Ana Briones-Pérez.

Identification of molds associated with green table olives

F. Pérez-Nevado, P.P. Mateos, A. Hernández, A. Martín, M.J. Benito, S. Ruiz-Moyano and M.G. Córdoba.

In vitro effect of lactic acid bacteria isolated from guirra sheep against Salmonella spp. C.M. Amorocho Cruz, J. García Hernández, Y. Moreno Trigos, A. Jiménez Belenguer,

M.A. Ferrús Pérez and M. Hernández Pérez

Lactic acid bacteria from wines from Ribeira Sacra (Spain): isolation, identification and characterization of some oenological properties

J.M. Mesas, M.T. Alegre Arribas and M.C. Rodríguez Pérez.

Occurrence of ochratoxin A in plasma from Valencian citizens and resemblance with previous Spanish data

A. Medina, F. Mateo, Eva M. Mateo, R.J. Roig, A. Blanquer, V. Mirabet and M. Jiménez

Partial fermentation of musts from Tempranillo dried grapes

N. López de Lerma, J.J. Moreno and R.A. Peinado

Presence of Arcobacter spp. contamination in fresh lettuces for human consumption

A. González, E. Yeres, C.M. Gentil de Farias, Y. Moreno and M.A. Ferrús

Production of patulin by Penicillium expansum in different culture media including bee pollen media F.M. Valle-Algarra, Eva M. Mateo, M.A. García-Esparza, R. Mateo, J.V. Gimeno-Adelantado and M. Jiménez

Selection of Oenococcus oeni as starter cultures to induce malolactic fermentation in Nebbiolo wine Antonella Costantini, Francesca Doria, Enrico Vaudano, Maria Carla Cravero and Emilia Garcia-Moruno

Species specific PCR detection protocol for the main mycotoxin-producing Aspergillus species in paprika N. Sardiñas Díaz, J. Gil-Serna, B. Patiño Álvarez, M.T. González-Jaén and C. Vázquez Estévez

Standardisation and optimisation of the Alkaline-Tolerance Response (AlTR) in Listeria monocytogenes 10403S

Efstathios S. Giotis, Ian S. Blair and David A. McDowell

Study of cell envelope proteinase systems of natural isolated thermophilic lactobacilli

I. Bazukyan, N. Ahabekyan, R. Madoyan, M. Dalgalarrondo, J.-M. Chobert, Yu. Popov and

T. Haertlé.

Yeast, beer and fermentation: an opportunity to involve young students in biotechnology Javier Méndez Viera, Joan J. Guinovart and Josep M. Fernández-Novell.

\section{Medical and Pharmaceutical Microbiology}

An efficient molecular typing assay for Alternaria spp. isolates

A. Lança, I. Almeida, H.M. Martins, F. Bernardo, M. Guerra, J. Inácio and M.L. Martins 
Anatomopathological and mycological findings in two seagull (Larus sp.) infected by Aspergillus fumigatus

H. Martins, P. Carvalho, P. Mendonça and M. Monteiro

Antimicrobial activity of Thymus vulgaris, Matricaria chamomilla, Croton lechleri, Calendula officinalis

L., Julliana adstringens Schl against periodontophatogen microorganisms

A. Rodríguez García, L.J. Galán Wong, G. Rojas Verde and K. Arévalo Niño

Chemical and pharmacological study of Brazilian marine Streptomyces Ana Claudia Granato, Luis H. Romano, Jaine H.H.L. Oliveira, Regiane P. Ratti, Isara L.C. Hernandez, Raquel C. Montenegro, Marlei Barboza, Cristina P. Souza, Carlos $O$. Hokka and Milan Trsic.

Determination of mode of action for novel synthetic antifungal agents using reversal assay method M. Mahboubi, S. Sardari, V. Khalaj and M. Mehravar....

Effect of plants used in Mexican traditional medicine on Candida albicans biofilm J. Sardi-de Cássia Orlandi, I. Peixoto-Teixeira Alves, J.F. Höfling, B. Gonçalves-Reginaldo, A. Rodríguez-García, L.J. Galán-Wong, K. Arévalo-Niño, C. Pierce and J.L. López-Ribot .

In vitro evaluation of biopolymers as delivery system of plant extracts on cultures of Porphyromonas gingivalis and Agreggatibacter actinomycetemcomitans

A. Rodríguez García, L.J. Galán Wong, J. Verde Star, M.S. Flores González and K. Arévalo Niño .....

In vitro tests of antifungal activity of plants used in Mexican traditional medicine

I. Peixoto Teixeira Alves, M.A. De la Garza-Ramos, L.J. Galán Wong, K. Arévalo Niño and

A. Rodríguez García

In vitro tests of biopolymers with extracts from plants used in Mexican traditional medicine on Candida albicans biofilm

J. de Cássia Orlandi Sardi, I. Teixeira Alves Peixoto, J.F. Höfling, R. Bruno Gonçalves,

A. Rodríguez García, L.J. Galán Wong, K. Arévalo Niño, J.L. López Ribot and C. Pierce

Influence of patient care with invasive devices on the risk of healthcare-associated infections Diana Platace, Ilze Klava, Lilija Antonevica, Aigars Reinis, Valentina Kuznecova, Juta Kroica and Inga Millere.

Invasive infection by Trichosporon mucoides following circovirus infection in a parrot H. Martins, P. Carvalho, P. Mendonça, T. Fagulha, A.M. Henriques and M. Monteiro

Isolation and screening of soil microorganisms for membrane-active antimicrobial metabolites M. Mehravar, S. Sardari, M. Mahboubi and P. Owlia.

Lactic acid bacteria from the vagina of healthy Turkish women: identification, hydrogen peroxide production

Merih Kıvanç, Demet Yazıcıoğlu and Emine Dinçer....

Methicillin-resistant Staphylococcus aureus in Brazil: classification of SCCmec and virulence factors M.V. Pimenta Rodrigues, C. Sena Martins de Souza, N.B. Teixeira, C.M. Castelo Branco Fortaleza and M.L. Ribeiro de Souza da Cunha

Polyphasic characterization of Aspergillus fumigatus strains causing infection in parrots and dolphins A. Lança, I. Almeida, H.M. Martins, F. Bernardo, M. Guerra, J. Inácio and M.L. Martins ....

Streptococcus intermedius trigger quorum-sensing genes in Porphyromonas gingivalis M.A. De la Garza-Ramos, A. Alcázar-Pizaña, M. Garza-Enriquez, R. Caffesse, V. Aguirre-Arzola, L.J. Galán-Wong and B. Pereyra-Alférez

Synergistic antimicrobial activity among hydroalcoholic extract of leaves of trees in the Brazilian territory common

Cristiane Karina Malvezzi, Jacqueline Stella Barbosa de Souza and Silvio Silvério da Silva 
Syzygium aromaticum (clove) extract reduce virulence factors mediated by QS in Gram negative bacteria F. Llinares, M.J. Pozuelo, S. Casado, C. de Blas, J.A. Pinilla, J. García de los Ríos and P.A. Jiménez

\section{Biotechnologically Relevant Enzymes and Proteins}

Biotechnological potential of an extracellular peroxidase from Streptomyces albus A.S. Ball, C. Kleisiari, M. Hernández and M.E. Arias

Characterization of the optimal conditions for the cultivation of Cladosporium cladosporioide (Fres.)

de Vries and isolation of the pectinase produced in solid-state conditions

S. Carvalho Bastos, C. José Pimenta, S. Maria Chalfoun Souza, L. Silveira Tavares,

Disney Ribeiro Dias and L. Martinez Abreu Soares Costa...

Comparative study of modified versus natural human basic Fibroblast Growth Factor (hbFGF) in survival and proliferation of $3 \mathrm{~T} 3$ cells

Amir Amanzadeh, Mona Alibolandi, Mojgan Khayat Moghadam and Hasan Mirzahoseini....

Effect of cell surface components on ASABF- $\alpha$ susceptibility in Staphylococcus aureus: a resistance mechanism involving cell wall alteration

Melody Tsai, Yusuke Kato and Kazuya Morikawa....

Exploring the biotechnological applications of a halotolerant $\mathrm{pH}$-versatile laccase produced by

Streptomyces ipomoea CECT 3341

Manuel Hernández, Raquel Moya, José M. Molina-Guijarro, Francisco Guillén and

M. Enriqueta Arias....

Heterologous proteins expression in Escherichia coli: investigation of the effect of codon usage and expression host optimization

Hasan Mirzahoseini, Samaneh Mafakheri, Somayeh Enayati and Nahid Mortazavi

Production of amylases, CMCases, xylanases and ligninolytic enzymes by white-rot fungi in solid and liquid fermentation

G. Rojas-Verde, M.M. Iracheta-Cárdenas, L.J. Galán-Wong and K. Arévalo-Niño

Utilization of agroindustrial residues as substrates for production of pectinolytic enzymes by the biological agent "G088"

C. José Pimenta, L. Martinez Abreu Soares Costa, S. Maria Chalfoun, M. Cláudio Pereira,

S. Carvalho Bastos and L. Silveira Tavares.

\section{Microfactories - Microbial Production of Chemicals and Pharmaceuticals}

Bacteriocin production by bean root bacteria

Çĭgdem Küçük and Merih Kıvanç

Biosynthesis of amino acids sulfur in Saccharomyces cerevisiae is affected by fermentation conditions in beer production

C.S. Leal-Guerra, E. Pérez-Ortega, L. Damas-Buenrostro, J.C. Cabada, L. Galán-Wong and

B. Pereyra-Alférez.

Chitin and chitosan produced by Mucoralean fungi using a new economic medium corn steep

T.C.M. Stamford, M.C. Freitas Silva, L.R.R. Berger, F.S.C. Anjos, S.R.C. Alcântara,

N.P. Stamford and G.M. Campos-Takaki......

Extraction of clavulanic acid in aqueous two-phase systems followed by separation through ultrafiltration

G. Youssef Rodriguez, C. Sacardo da Silva, C. Osamu Hokka and M. Barboza.

Growing kinetics and antimicrobial activity of Streptomyces tubercidicus crude extracts

R. Priscila Ratti, A.C.M. Toledo Piza, A.C. Granato, C.O. Hokka, J.D. Dubreuil and

C. Paiva de Sousa . 
Isolation and antimicrobial activity of Streptomyces tubercidicus against pathogenic bacteria and fungi

R. Priscila Ratti, A.C.M. Toledo Piza, A.C. Granato, C.O. Hokka and C. Paiva de Sousa

Isolation, phenogenotypic idenfication and bioactivity evaluation of endophytic microorganisms intrinsically associated with Miconia albicans in Brazilian tropical savannah tree in Sao Carlos, SP

A.C.M. Toledo Piza, R. Priscila Ratti, N.F.G. Serrano, C.O. Hokka, J. Daniel Dubreuil and

C. Paiva de Sousa

Transformation of nerol with Aspergillus niger in Czapek-Dox medium

Takehiko Tsuruta

Xylitol production from dilute-acid hydrolysis of bean group shells

Chizuru Sasaki, Akihiro Kurosumi, Yuya Yamashita, Godliving Mtui and Yoshitoshi Nakamura

\section{Microbial Physiology, Metabolism and Gene Expression}

A YARE-like element as the binding site for specific KlHIS4 transcriptional regulators and its implication in cadmium toxicity

M. Lamas-Maceiras and M.A. Freire-Picos

Alterations induced by transition metals nickel, cadmium and mercury in Salmonella typhimurium growth and membrane proteins

Hossein Tayefi-Nasrabadi and Ezzatollah Keyhani

Assaying the single and combined genotoxicity of Calotropis procera Ait latex and chlorcyrin in Aspergillus terreus

Jamal S.M. Sabir.

Construction of a plasmid vector for thermoacidophilic crenarchaeon Sulfolobus acidocaldarius Yoko Kawasaki and Norio Kurosawa

Effect of cyanide and azide on growth and membrane proteins in Salmonella typhimurium

D. Minai-Tehrani, M. Veissizadeh, E. Keyhani and J. Keyhani.

Influence of the $M T H$ genes on synthesis of alcohol oxidase and catalase in methylotrophic yeasts

Pichia methanolica

E.P. Isakova, Y.I. Deryabina and O.A. Leonovich

Mobility of Stv1p and Vph1p, the "a" subunit isoforms of the Saccharomyces cerevisiae vacuolar

ATPase through late secretory pathway membranes

I. Corbacho, F. Teixidó, R. Velázquez, I. Olivero and L.M. Hernández

The genotoxicity of three synthetic pesticides: chlorpyrifos, cypermethrin and their mixture chlorcyrin in Aspergillus terreus

Jamal S.M. Sabir

Transcriptional regulation of ADE2 and PUT2 genes in Kluyveromyces lactis

G. Ruiz Moran, M. Lamas Maceiras and A.M. Rodriguez Torres .....

Yeast vacuole staining using quinacrine and neutral red

I. Corbacho, F. Teixidó, R. Velázquez, L.M. Hernández and I. Olivero

\section{Methods}

A cheminformatics approach to an enriched database of antimycobacterial compounds useful for drug discovery pipeline

S. Sardari, B. Shaghaghi and H. Borna

Aggregation-based in silico study for better understanding of related membrane interfering analogous of Amphotericin B

S. Sardari, S. Mostaan and P. Azerang..... 
Bacterial growth as nonlocal coherent phenomenon

Marcin Molski

Capacity of neural network models to predict deoxynivalenol build-up in barley grain contaminated in vitro with Fusarium culmorum

F. Mateo, A. Medina, Eva M. Mateo, F.M. Valle-Algarra and M. Jiménez.

Determination of cell cycle parameters by flow cytometry in bacteria: practical considerations

F. Molina, M. Mota, M.A. Sánchez-Romero and A. Jiménez-Sánchez.

Determination of ethanol in alcoholic drinks using an enzyme biosensor containing alcohol

dehydrogenase

V. Polan and K. Vytras.

Growth of Penicillium expansum and production of patulin in potato-glucose-agar medium supplemented with imazalil

F.M. Valle-Algarra, Eva M. Mateo, F. Mateo, J.V. Gimeno-Adelantado and M. Jiménez.

Metabolic reconstruction of Synechococcus elongatus towards a minimal photoautotrophic cell

C.M. González-Domenech, J. Puchałka, V.A.P. Martins dos Santos, J. Peretó, A. Moya and

L. Delaye

Nanocurvatures and "nanocup" formation induced by ethidium bromide in yeast plasma membrane

Ezzatollah Keyhani

Selectivity-refined in silico analogue finding method for new antifungal molecules based on amphotericin B molecular features

M. Ferdosiyan and S. Sardari.

Structure activity relationship study of the $\beta$-lactamase inhibitors and theoretical design for new bioactive compounds

Ana Claudia Granato, Edson B. Costa, Marlei Barboza and Milan Trsic .... 


\title{
Quantification and toxicity testing of pharmaceuticals in tropical marine sediments, All Saints Bay, Bahia, Brazil
}

\author{
M. Beretta, L. Wessels Perelo* and I. Brandão de Oliveira \\ UFBA - DEA, Department of Environmental Engineering, Federal University of Bahia, Rua Prof. Aristides Novis \\ 02, 40210-910 Salvador, Brazil
}

\begin{abstract}
The presence and effects of pharmaceuticals in the environment have gained increased attention lately because of their widespread use and their potential to bioaccumulate and induce negative effects in aquatic and terrestrial ecosystems. This work presents the quantification of pharmaceutical compounds in sediments of All Saints Bay, Bahia, Brazil and toxicity testing of the compounds Atenolol, Erythromycin and Caffeine on sediment microorganisms and microcrustaceans (Artemia salina). Pharmaceuticals were shown to be widely distributed in sediments of All Saints Bay, in areas near the capital Salvador as well as in more remote areas of the bay. Toxicity tests revealed a susceptibility of microorganisms and microcrustaceans to both Erythromycin and Caffeine at higher concentrations, while Atenolol did not cause toxic effects. The presence of pharmaceuticals at the levels detected did not imply acute toxicity to microorganisms and microcrustaceans.
\end{abstract}

Keywords: pharmaceuticals; tropical marine sediment; microbial toxicity; brine shrimp assay.

\section{Introduction}

Until the 1990s pharmaceuticals did not attract significant attention as a potential group of environmental contaminants. This changed when it was discovered that some compounds have the ability to interfere with the ecosystem even in lowest concentrations [1] and with the development of more sensitive analytical techniques.

The main routes by which these compounds enter aquatic ecosystems are municipal wastewaters, but they are also introduced to the environment by disposal of unused or expired medicines, wastewater from manufacturers and landfill leachates [2,3]. As pharmaceuticals are developed to have some kind of biological function and persistence in the organisms applied to, they also have a potential to bioaccumulate and induce effects in aquatic and terrestrial ecosystems [1]. Monitoring studies have shown that pharmaceuticals and their metabolites are very resistant to most water treatment techniques and are present in all kinds of aquatic systems $[4,5]$.

Biodegradation by microorganisms is the main mechanism to eliminate organic compounds from the environment. The main groups involved in degradation processes are bacteria and fungi, the latter being predominant in soils, while bacteria are of major importance in the aquatic environment, including wastewater treatment [6]. Bioactive compounds as pharmaceuticals may have toxic effects on bacteria, especially the antibiotics that are designed to combat bacterial diseases and thereby may interfere with the degradation processes of these substances in the environment. Data on toxic effects of pharmaceuticals on sediment bacteria are necessary to evaluate the fate, persistence and thereby the risk inherent to these compounds in the environment.

In Brazil, data on the presence of pharmaceuticals in the aquatic environment are still scarce, while the consumption of these compounds suffers little control and disposal of expired drugs is indiscriminate. The Brazilian government does not make demands on security or quantity limits regarding the discharge of pharmaceuticals to water bodies. Most of the data available refer to the subtropical South of Brazil [7,8].

The objective of this study was to identify and quantify the pharmaceuticals present in the tropical marine environment of All Saints Bay as well as evaluate the toxicity of some of these compounds to marine microcrustaceans and sediment microorganisms.

\section{Materials and Methods}

\subsection{Study area}

All Saints Bay is located in the state of Bahia, in the tropical northeast of Brazil, on $12^{\circ} 50^{\prime} \mathrm{S}$ and $38^{\circ} 38^{\prime} \mathrm{W}$. It is the second largest bay in Brazil, with an extension of $1233 \mathrm{~km}^{2}$ and an average depth of $9.8 \mathrm{~m}$. The bay has a shoreline of $300 \mathrm{~km}$ and contains fifty-six islands. The largest terrestrial oil reservoirs of Brazil are located in the adjacent continent Part of the bays shoreline adjoins the third major metropolitan area in Brazil, the city of Salvador and the largest petrochemical complex in the southern hemisphere (Camaçari Petrochemical Center) [9]. Most important harbors within the bay are the harbor of the city of Salvador and the harbor of Aratu.

\footnotetext{
* Corresponding author: e-mail: louperelo@gmail.com, phone: +55 7132839790
} 
Sediment structure varies from muddy to coarse sand. Muddy bottom sediment predominates in the northern part of the bay, whereas its southern part presents an accumulation of medium to very coarse sands. Since its discovery in the sixteenth century, All Saints Bay has been heavily used, from mining of calcareous sands, to petroleum exploration, over fishing, industrial sewage and intensive tourism [10].

Seventeen sampling points throughout the bay were selected for the determination of pharmaceuticals in sediments (Fig. 1).
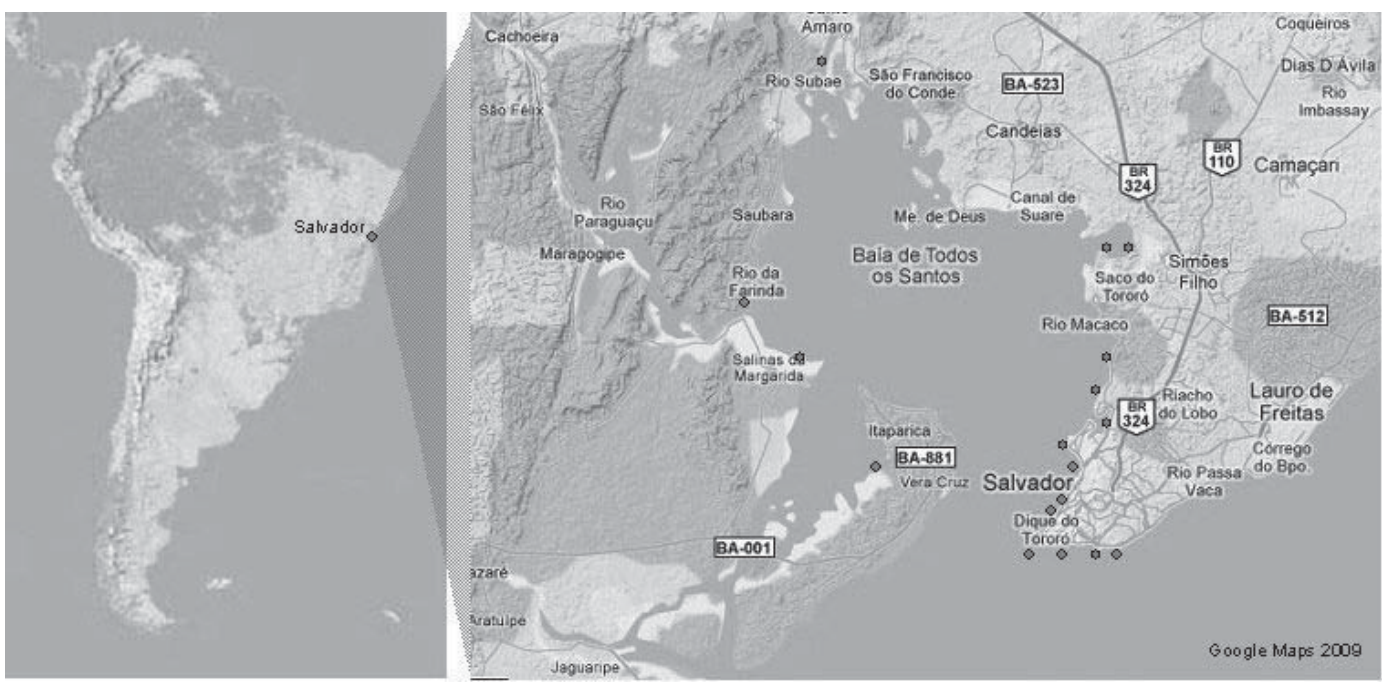

Fig. 1 Location of the 17 sampling points in All Saints Bay, State of Bahia, Brazil.

\subsection{Quantification of pharmaceuticals}

Sediment from 17 sampling points in the All Saints Bay were analyzed for the occurrence of pharmaceutical compounds: Samples were extracted in ultrasound, filtered, purified and quantified by Liquid Chromatography coupled to tandem Mass Spectrometry (LC-MS/MS), and Gas Chromatography and Mass Spectrometry (GC/MS). Analyses were realized at the University of La Coruña, Spain.

\subsection{Toxicity tests}

Test organisms (brine shrimp and sediment microorganisms) were exposed to Atenolol, Erythromycin and Caffeine in concentrations ranging between 0.002 and $2.0 \mathrm{mg} / \mathrm{ml}$. Solutions of Atenolol and Erythromycin were made by dissolving commercially available pharmaceuticals, while caffeine was used as a pure substance. The concentration range tested was determined according to preliminary sensitivity tests. The microcrustacean $A$. salina was exposed to solutions of Atenolol and Erythromycin of $0.125 \mathrm{mg} \mathrm{ml}^{-1}, 0.25 \mathrm{mg} \mathrm{ml}^{-1}$ and $0.5 \mathrm{mg} \mathrm{ml}^{-1}$ and to Caffeine in concentrations of $2.0 \mathrm{mg} \mathrm{ml}^{-1}, 0.2 \mathrm{mg} \mathrm{ml}^{-1}$ and $0.02 \mathrm{mg} \mathrm{ml}^{-1}$. For tests with sediment microorganisms, concentrations of $0.002 \mathrm{mg} \mathrm{ml}^{-1}, 0.02 \mathrm{mg} \mathrm{ml}^{-1}$ and $0.2 \mathrm{mg} \mathrm{ml}^{-1}$ were used for the three pharmaceuticals.

Cysts of Artemia salina were hatched in artificial seawater (Tetra Marine Salt) and 24 h old nauplii were used for toxicity testing in the Brine Shrimp Assay [11]. Five nauplii of Artemia salina were placed in $10 \mathrm{ml}$ of test solutions and in artificial seawater as controls. After 48 hours, surviving nauplii were counted. All experiments were conducted in triplicate.

Toxicity to sediment microorganisms was tested with sediments collected from the shore area of All Saints Bay. 0.25 to $0.5 \mathrm{~g}$ of marine sediment was suspended in $100 \mathrm{ml}$ of sterile marine water. The microorganisms in $1 \mathrm{ml}$ of sediment suspension were exposed to varying concentrations of Atenolol, Erythromycin and Caffeine in solution, added to Plate Count Agar $(3.5 \% \mathrm{NaCl})$ by the pour plate technique [12]. Controls received sediment suspension and sterile diluting water on Plate Count Agar. For each dilution, plates were prepared in duplicate and incubation was realized at $35^{\circ} \mathrm{C}$. After 24 hours, colony-forming units (CFUs) on the $65-\mathrm{cm}^{2}$ plates were counted with a Darkfield Quebec Colony Counter. On plates with less than $10 \mathrm{CFUs,} 13 \mathrm{~cm}^{2}$ with a representative colony distribution were counted, while on plates with more than 10 CFUs only $4 \mathrm{~cm}^{2}$ were counted and results were extrapolated to the whole plate area of $65 \mathrm{~cm}^{2}$. Thus results could be expressed in CFU ml ${ }^{-1}$. 


\section{Results and Discussion}

\subsection{Quantification of pharmaceuticals}

Atenolol and Caffeine were present at all seventeen sampling points in All Saints Bay (BTS), while Erythromycin was only present at $29 \%$ of the sampling sites. Atenolol was also predominant with a mean concentration of $6.0 \mathrm{ng} \mathrm{g}^{-1}$ dry weight (dw). Caffeine, which has been shown to be an effective tracer of organic pollution from wastewater sources [13], was present in all samples with a mean concentration of $2.57 \mathrm{ng} \mathrm{g}^{-1} \mathrm{dry}^{-1}$ weight and reaching maximum concentrations of $23.45 \mathrm{ng} \mathrm{g}^{-1} \mathrm{dw}$ (Fig. 2). These findings are consistent with/ contrary to concentrations measured by Stackelberg [14] in United States in 2007.

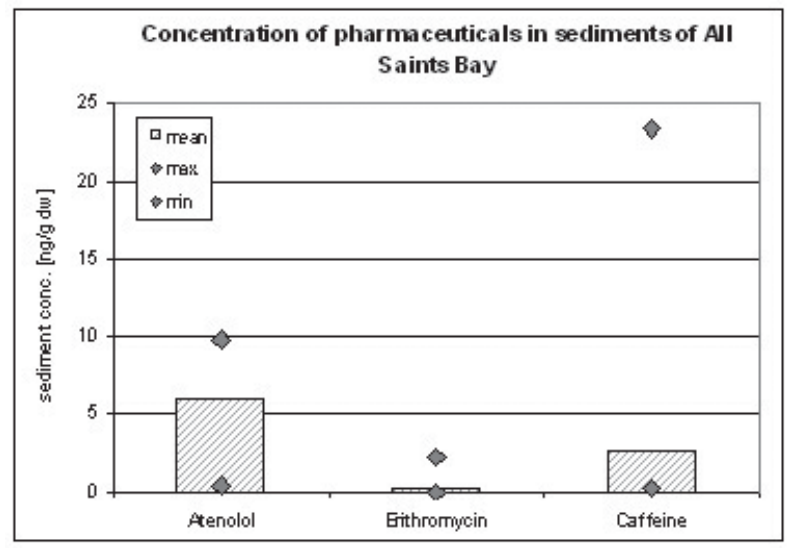

Fig. 2 Concentration of Atenolol, Erythromycin and Caffeine in sediments of 17 sampling points in All Saints Bay. Columns show the mean concentration of all sampling points; Points indicate the highest and lowest concentrations measured.

Atenolol belongs to the beta-blockers and is a commonly used pharmaceutical in cardiovascular diseases. Erythromycin is a macrolide antibiotic and inhibits protein synthesis interacting with bacterial ribosomes. Caffeine is most commonly consumed as an ingredient of coffee, tea, chocolate and soft drinks, but is also medicinally used as a cardiac, cerebral, and respiratory stimulant and also functions as a diuretic [15]. Due to its high consumption rate it may serve as a tracer of organic pollution [16].

Pharmaceuticals enter the environment primarily through wastewater discharges due to their low removal rate in wastewater treatment plants (WWTPs). The removal rate of Atenolol in WWTPs is lower than 10\% [17]. Jones [18] gives a total removal of $1.85 \%$, of which only $0.09 \%$ is due to biodegradation. Also for Erythromycin total removal rates and total biodegradation rates are low, with $6.23 \%$ and $0.13 \%$, respectively. Caffeine on the other hand was proved to be readily biodegradable, resulting in high removal rates during sewage treatment processes [19].

\subsection{Toxicity tests}

Nauplii or cysts of Artemia have been shown to be sensitive to wide variety of contaminants, including antibiotics, and have been found suitable for testing seawater soluble drug pollutants [20,21].

In our toxicity tests with nauplii of Artemia salina, a mortality rate of $>20 \%$ was considered toxic effect. The test organisms showed highest susceptibility to the antibiotic Erythromycin, resulting in more than $90 \%$ mortality at $0.5 \mathrm{mg} \mathrm{mL}^{-1}$. Caffeine had a comparable effect, while Atenolol did not seem to cause toxic effects in the concentration range tested, considering the limit of $20 \%$, even though increasing concentration resulted in higher mortality rates (Fig. 3a). Higher concentrations of Atenolol were not tested due to the high turbidity of the solution, which would have made it impossible to count surviving nauplii. LC50 values reported in literature for Atenolol is $33.4 \mathrm{mg} \mathrm{L}^{-1}$ for cladocerans and $620 \mathrm{mg} \mathrm{L}^{-1}$ for algae [22]. Fish may be more affected by betablockers as they contain 32 -receptors in heart and liver [23] and the related drug propanolol indicated chronic toxicity effects on the cardiovascular system [17]. Nauplii of Artemia salina were much more sensible to Erythromycin and Caffeine than Daphnia magna used in standardized toxicity assessments. Thus, LC50 of Erythromycin for daphnids was reported to be $211 \mathrm{mg} \mathrm{L}^{-1}$ [24], while in our experiments the lethal dose for $50 \%$ of Artemia was between 0.25 and $0.5 \mathrm{mg} \mathrm{L}^{-1}$. For Caffeine LC50 values of $182 \mathrm{mg} \mathrm{L}^{-1}$ for cladocerans have been reported [25], while we found that about $0.2 \mathrm{mg} \mathrm{L}^{-1}$ of caffeine resulted in $50 \%$ mortality of Artemia nauplii. As nearly $84 \%$ of caffeine is demethylated to paraxanthine, the concentrations of caffeine found in sediment might be significantly lower than the load of caffeine received by the water column.

During tests with sediment microorganisms, a reduction of CFUs of $20 \%$ compared to controls was considered toxic effect. Sediment microorganisms, particularly aerobic superficial colonies were strongly inhibited by the antibiotic Erythromycin at concentrations of $0.2 \mathrm{mg} \mathrm{L}^{-1}$. Caffeine also inhibited bacterial growth 
at concentrations ten times higher than the antibiotic $\left(2.0 \mathrm{mg} \mathrm{L}^{-1}\right)$, while Atenolol had no effect on the number of colony forming units (CFUs) (Fig. 3b).

Caffeine has been shown to have antimicrobial effects on a variety of microorganisms, including human pathogens. For example the enterobacteria Salmonella enterica was inhibited in growth by a caffeine concentration of $2.6 \mathrm{mg} \mathrm{mL}^{-1}$ [26].
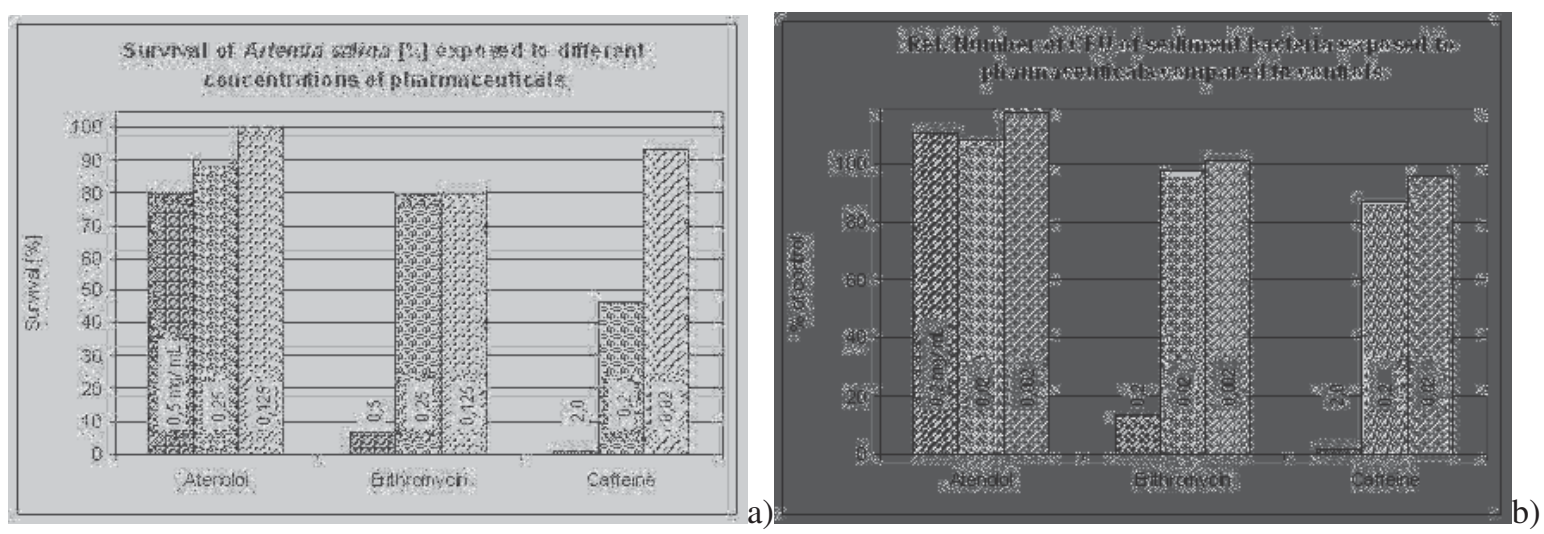

Fig. 3 Results of toxicity test with a) Artemia salina and b) colony forming sediment microorganisms.

The presence of compounds exhibiting antimicrobial activity in the environment is of concern, as microorganisms play a crucial role in degradation and therefore bioremediation processes. Even if the concentrations of these compounds measured in the environment are much lower than inhibition concentrations, the possibility of synergistic and additional effects of several compounds cannot be ruled out. Another concern regarding antibiotics in the environment, is the creation of low-level resistance in bacteria [27].

\section{Conclusions}

It can be assumed that the presence of pharmaceuticals at the levels detected do not imply acute toxicity to microorganisms and microcrustaceans, because the concentrations tested in toxicity assays were higher than the ones detected in the environment and the lower concentrations did not affect the test organisms.

Nevertheless it cannot be ruled out that these compounds do not have any influence on organisms, such as endocrine disruption, and synergistic or additive toxicity effects interacting in a mixture of chemical compounds. Seiler [28] emphasized the importance of more "mechanism-based" approaches to the investigation of potential environmental hazards, considering that pharmaceuticals, besides the primary effect they are designed for, may cause secondary effects considered irrelevant for the therapeutic activity in humans but may play a role in other organisms. Effects by exposure to pharmaceuticals may be sub-lethal, affecting reproduction or growth and thereby threaten the species survival. These effects may only be detectable during chronic longterm exposure.

Further studies should focus on persistence/ degradation dynamics of these compounds in the marine environment and on their chronic and combined toxicity to marine organisms.

\section{References}

[1] Halling-Sorensen, B; Nors Nielsen, S; Lansky, PF; Ingerslev, F; Holten Lutzhoft, HC; Jorgensen, SE Occurrence, fate, and effects of pharmaceutical substances in the environment- a review. Chemosphere. 1998;36:357-393

[2] Ellis JB. Pharmaceutical and personal care products in urban receiving waters. Environmental Pollution. 2006;144:184-189

[3] Sanderson H; Brain, RA; Johnson, DJ; Wilson, CJ; Solomon, KR. Toxicity classification and evaluation of four pharmaceuticals classes: Antibiotics, antieoplastics, cardiovascular, and sex hormones. Toxicology. 2004;203 27-40

[4] Gulkowska, A; He, YH; So, MK; Yeung, LWY; Leung, HW; Giesy, JP; Lam, PKS; Martin, M; Richardson, BJ. The occurrence of selected antibiotics in hong kong coastal waters. Mar Pollut Bull. 2007;54 1287-1293

[5] Kolpin DW; Furlong, ET; Meyer, MT; Thurman, EM; Zaugg, SD; Barber, LB; Buxton, HT. Pharmaceuticals, hormones, and other organic wastewater contaminants in us streams 1999-2000: A national reconnaissance. Environ Sci Technol. 2002;36:1202-1211

[6] Kümmerer K. Pharmaceuticals in the environment - a brief summary. In: K. K, ed. Pharmaceuticals in the environment - sources, fate, effects and risks. Berlin / Heidelberg: Springer 2008:521.

[7] Stumpf, TA; Wilkena, R-D; Vianna Rodrigues, S; Baumann, W. Polar drug residues in sewage and natural waters in the state of rio de janeiro, brazil. The Science of the Total Environment 1999;225 135-141 
[8] Ternes, M; Wilken, R; Rodrigues, SV; Baumann, W. Polar drug residues in sewage and natural waters in the state of Rio de Janeiro, Brazil. Sci Total Environ 1999;225:135

[9] Cyrano M; Lessa, GC. Oceanographic characteristics of Baía de Todos os Santos, Brasil. Revista Brasileira de Geofísica. 2007;25:363-367

[10] Leao ZMAN; Dominguez, JML. Tropical coast of brazil. Mar Pollut Bull. 2000;41:112-122

[11] Michael AS, Thompson, CG; Abramovitz, M. Artemia salina as a test organism for bioassay. Science. 1956;123:464

[12] APHA, American Public Health Association. Standard methods for the examination of water and wastewater. Washington; 1995.

[13] Sankararamakrishnan N; Guo, Q. Chemical tracers as indicator of human fecal coliforms at storm water outfalls. Environ Int. 2005;31:1133-1140

[14] Stackelber PE; Furlong, ET; Meyer, MT; Zaugg, SD; Henderson, AK; Reissman, DB. Persistence of pharmaceutical compounds and other organic wastewater contaminants in a conventional drinking-watertreatment plant. Sci Total Environ. 2004;329:99-113

[15] Buerge IJ; Poiger, T; Müller, MD; Buser, HR. Caffeine, an anthropogenic marker for wastewater contamination of surface waters. Environ Sci Technol. 2003;37:691-700

[16] Comeau F; Surette, C; Brun, GL; Losier, R. The occurrence of acidic drugs and caffeine in sewage effluents and receiving waters from three coastal watersheds in atlantic canada. Sci Total Environ. 2008;396:132-146

[17] Fent K; Weston, AA; Caminada, D. Ecotoxicology of human pharmaceuticals. Aquatic Toxicology. 2006;76:122-159

[18] Jones OAH; Voulvoulis, N; Lester, J.N. Aquatic environmental assessment of the top 25 english prescription pharmaceuticals. Water Research. 2002;36:5013-5022

[19] Heberer T. Tracking persistent pharmaceutical residues from municipal sewage to drinking water. J Hydrol. 2002;266:174-189

[20] Favilla M; Macchia, L; Gallo, A; Altomare, C. Toxicity assessment of metabolites of fungal biocontrol agents using two different (Artemia salina and Daphnia magna) invertebrate bioassays. Food and Chemical Toxicology. 2006;44:1922-1931

[21] Migliore L; Civitareale, C; Brambilla, G; Dojmi di Delupis, G. Toxicity of several important agricultrual antibiotics to artemia. Water Research. 1997;31:1801-1806

[22] Cunningham, VL; Buzby, M; Hutchinson, T; Mastrocco, F; Parke, N; Roden, N. Effects of human pharmaceuticals on aquatic life: Next steps. Environ Sci Technol. 2006;40:3456-3462

[23] Gamprel, A; Wilkinson, M; Boutilier, R. B-adrenoreceptor in the trout hearth: Characterisation, quantification and effects of repeated catecholamine exposure. Gen Comp Endocrinol. 1994;95:259-272

[24] Dojmi di Delupis G; Macri, A; Civitareale, C; Migliore, L. Antibiotics of zootechnical use: Effects of acute high and low dose contamination on daphnia magna straus. Aquat Toxicol. 1992;22:53-60

[25] Fernandez C; Gonzalez-Doncel, M; Pro, J; Carbonell, G; Tarazona, JV. Occurrence of pharmaceutically active compounds in surface waters of the henares-jarama-tajo river system (madrid, spain) and a potential risk characterization. Sci Total Environ. 2010;408:543-551

[26] Almeida AAP; Farah, A, Silva, DAM; Nunan EA; Gloria, MBA. Antibacterial activity of coffee extracts and selected coffee chemical compounds against enterobacteria. J Agric Food Chem. 2006;54:8738-8743

[27] Daughton CG; Ternes, TA. Pharmaceuticals and personal care products in the environment: Agents of subtle change? Environ Health Perspect. 1999;107:907-937

[28] Seiler JP. Pharmacodynamic activity of drugs and ecotoxicology—can the two be connected? Toxicology Letters. 2002;131:105-115 
[8] Ternes, M; Wilken, R; Rodrigues, SV; Baumann, W. Polar drug residues in sewage and natural waters in the state of Rio de Janeiro, Brazil. Sci Total Environ 1999;225:135

[9] Cyrano M; Lessa, GC. Oceanographic characteristics of Baía de Todos os Santos, Brasil. Revista Brasileira de Geofísica. 2007;25:363-367

[10] Leao ZMAN; Dominguez, JML. Tropical coast of brazil. Mar Pollut Bull. 2000;41:112-122

[11] Michael AS, Thompson, CG; Abramovitz, M. Artemia salina as a test organism for bioassay. Science. 1956;123:464

[12] APHA, American Public Health Association. Standard methods for the examination of water and wastewater. Washington; 1995.

[13] Sankararamakrishnan N; Guo, Q. Chemical tracers as indicator of human fecal coliforms at storm water outfalls. Environ Int. 2005;31:1133-1140

[14] Stackelber PE; Furlong, ET; Meyer, MT; Zaugg, SD; Henderson, AK; Reissman, DB. Persistence of pharmaceutical compounds and other organic wastewater contaminants in a conventional drinking-watertreatment plant. Sci Total Environ. 2004;329:99-113

[15] Buerge IJ; Poiger, T; Müller, MD; Buser, HR. Caffeine, an anthropogenic marker for wastewater contamination of surface waters. Environ Sci Technol. 2003;37:691-700

[16] Comeau F; Surette, C; Brun, GL; Losier, R. The occurrence of acidic drugs and caffeine in sewage effluents and receiving waters from three coastal watersheds in atlantic canada. Sci Total Environ. 2008;396:132-146

[17] Fent K; Weston, AA; Caminada, D. Ecotoxicology of human pharmaceuticals. Aquatic Toxicology. 2006;76:122-159

[18] Jones OAH; Voulvoulis, N; Lester, J.N. Aquatic environmental assessment of the top 25 english prescription pharmaceuticals. Water Research. 2002;36:5013-5022

[19] Heberer T. Tracking persistent pharmaceutical residues from municipal sewage to drinking water. J Hydrol. 2002;266:174-189

[20] Favilla M; Macchia, L; Gallo, A; Altomare, C. Toxicity assessment of metabolites of fungal biocontrol agents using two different (Artemia salina and Daphnia magna) invertebrate bioassays. Food and Chemical Toxicology. 2006;44:1922-1931

[21] Migliore L; Civitareale, C; Brambilla, G; Dojmi di Delupis, G. Toxicity of several important agricultrual antibiotics to artemia. Water Research. 1997;31:1801-1806

[22] Cunningham, VL; Buzby, M; Hutchinson, T; Mastrocco, F; Parke, N; Roden, N. Effects of human pharmaceuticals on aquatic life: Next steps. Environ Sci Technol. 2006;40:3456-3462

[23] Gamprel, A; Wilkinson, M; Boutilier, R. B-adrenoreceptor in the trout hearth: Characterisation, quantification and effects of repeated catecholamine exposure. Gen Comp Endocrinol. 1994;95:259-272

[24] Dojmi di Delupis G; Macri, A; Civitareale, C; Migliore, L. Antibiotics of zootechnical use: Effects of acute high and low dose contamination on daphnia magna straus. Aquat Toxicol. 1992;22:53-60

[25] Fernandez C; Gonzalez-Doncel, M; Pro, J; Carbonell, G; Tarazona, JV. Occurrence of pharmaceutically active compounds in surface waters of the henares-jarama-tajo river system (madrid, spain) and a potential risk characterization. Sci Total Environ. 2010;408:543-551

[26] Almeida AAP; Farah, A, Silva, DAM; Nunan EA; Gloria, MBA. Antibacterial activity of coffee extracts and selected coffee chemical compounds against enterobacteria. J Agric Food Chem. 2006;54:8738-8743

[27] Daughton CG; Ternes, TA. Pharmaceuticals and personal care products in the environment: Agents of subtle change? Environ Health Perspect. 1999;107:907-937

[28] Seiler JP. Pharmacodynamic activity of drugs and ecotoxicology—can the two be connected? Toxicology Letters. 2002;131:105-115 